
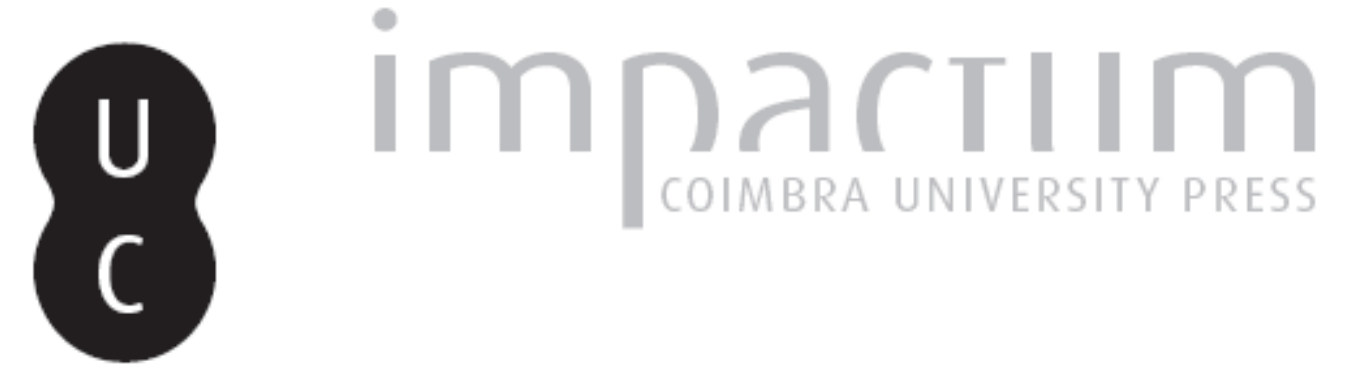

\title{
O uso do sistema de informação geográfica na identificação da susceptibilidade à erosão na zona de amortecimento de áreas protegidas brasileiras
} \author{
$\begin{array}{ll}\text { Autor(es): } & \text { Reis, Taiana Evangelista dos; Costa, Vivian Castilho da; Ribeiro, Marta } \\ & \text { Foeppel }\end{array}$ \\ Publicado por: $\quad$ Associação Portuguesa de Riscos, Prevenção e Segurança; Imprensa \\ da Universidade de Coimbra \\ URL \\ persistente: \\ URI:http://hdl.handle.net/10316.2/38063 \\ DOI: $\quad$ DOI:http://dx.doi.org/10.14195/1647-7723_22_10
}

Accessed : $\quad$ 26-Apr-2023 10:48:30

A navegação consulta e descarregamento dos títulos inseridos nas Bibliotecas Digitais UC Digitalis, UC Pombalina e UC Impactum, pressupõem a aceitação plena e sem reservas dos Termos e Condições de Uso destas Bibliotecas Digitais, disponíveis em https://digitalis.uc.pt/pt-pt/termos.

Conforme exposto nos referidos Termos e Condições de Uso, o descarregamento de títulos de acesso restrito requer uma licença válida de autorização devendo o utilizador aceder ao(s) documento(s) a partir de um endereço de IP da instituição detentora da supramencionada licença.

Ao utilizador é apenas permitido o descarregamento para uso pessoal, pelo que o emprego do(s) título(s) descarregado(s) para outro fim, designadamente comercial, carece de autorização do respetivo autor ou editor da obra.

Na medida em que todas as obras da UC Digitalis se encontram protegidas pelo Código do Direito de Autor e Direitos Conexos e demais legislação aplicável, toda a cópia, parcial ou total, deste documento, nos casos em que é legalmente admitida, deverá conter ou fazer-se acompanhar por este aviso.

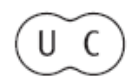




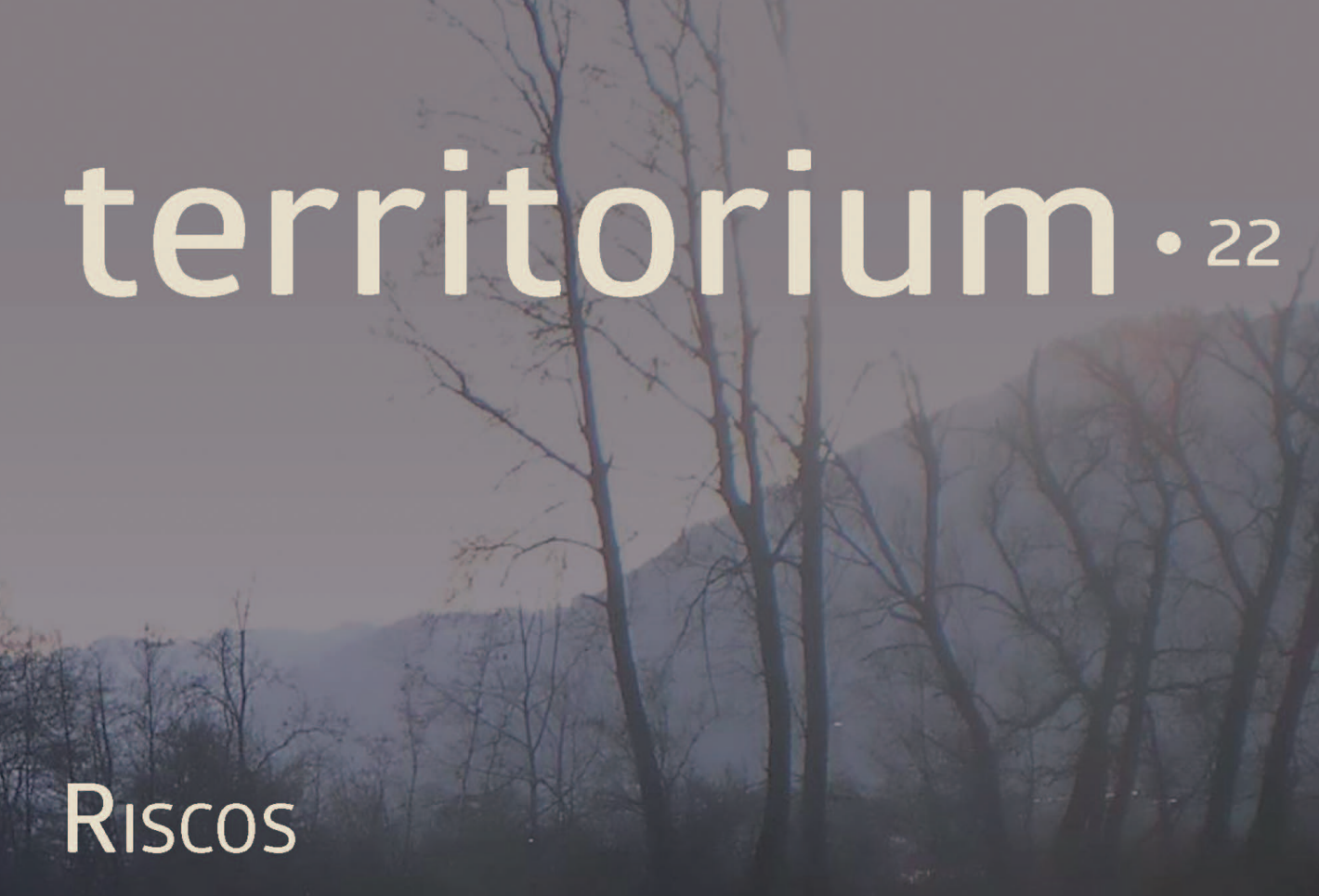

\section{TERRITÓRIOS DE CONVERGÊNCIA}

- Imprensa da Universidade de Coimbra Associação Portuguesa de:Riscos, Prevenção e Segurança 


\section{O USO DO SISTEMA DE INFORMAÇÃO GEOGRÁFICA NA IDENTIFICAÇÃO DA SUSCEPTIBILIDADE À EROSÃO NA ZONA DE AMORTECIMENTO DE ÁREAS PROTEGIDAS BRASILEIRAS*}

\section{THE USE OF GEOGRAPHIC INFORMATION SYSTEM TO IDENTIFY THE SUSCEPTIBILITY TO EROSION IN THE BUFFER ZONE OF PROTECTED AREAS IN BRAZIL}

Taiana Evangelista dos Reis

Doutoranda em Geografia, Universidade do Estado do Rio de Janeiro taiana.geo@gmail.com

Vivian Castilho da Costa

Departamento de Geografia Física, Universidade do Estado do Rio de Janeiro vivianuerj@gmail.com

Marta Foeppel Ribeiro

Departamento de Geografia Física, Universidade do Estado do Rio de Janeiro mfoeppel@gmail.com

\section{RESUMO}

Para preservar e manter a biodiversidade e os recursos naturais no Brasil, são criadas Unidades de Conservação da Natureza, cujas áreas envolventes são denominadas de Zona de Amortecimento (ZA), e que representam locais protegidos pela lei, onde as atividades devem ser mais restritas. O Parque Estadual do Ibitipoca (PEI) está localizado no Estado de Minas Gerais. O presente trabalho visa estudar e mapear os conflitos de uso e ocupação do solo em áreas susceptíveis à erosão na ZA do PEI, utilizando para tal, técnicas de geoprocessamento.

Palavras-chave: Zona de amortecimento, geoprocessamento, susceptibilidade à erosão.

\section{ABSTRACT}

To preserve and maintain biodiversity and the natural resources in Brazil are created / Nature Conservation Units, in that areas around it are called buffer zone (BZ) and are protected by local law, where the activities should be restricted. The Ibitipoca State Park (ISP) is located in the state of Minas Gerais. The aims of this work is studying and mapping the conflicts of use and occupation in areas susceptible to erosion in the BZ of the ISP, using for this, geoprocessing techniques.

Keywords: Buffer zone, geographic information system, susceptibility to erosion.

\section{RESUMEN}

El uso de sistemas de información geográfica para la identificación de la susceptibilidad a la erosión en la zona de amortiguamiento de las áreas protegidas de Brasil - Para preservar y mantener la biodiversidad y los recursos naturales en Brasil son creadas Unidades de Conservación de la Naturaleza, cuyas áreas circundantes se denominan zona de amortiguamiento (ZA) , o sea, locales protegidos por la ley, en que las actividades deben ser más restringidas. El Parque Estatal Ibitipoca (PEI) se encuentra en el estado de Minas Gerais. Este trabajo tiene como objetivo estudiar y cartografiar los conflictos de uso y ocupación del suelo en áreas susceptibles a la erosión en la ZA del PEl, mediante el uso de las técnicas de geoprocesamiento.

Palabras clave: Zona de amortiguamiento, geoprocesamiento, susceptibilidad a la erosión.

\section{RÉSUMÉ}

Utilisation des systèmes d'information Géographique pour identifier la susceptibilité érosive dans la zone tampon des aires protégées brésiliennes - - Des Unités de Conservation de la Nature ont été créées au Brésil afin de préserver et maintenir la biodiversitéetbiodiversité et les ressources naturelles. Autour de celles-ci, il existe des zones appelées Zones Tampon (ZT) qui représentent des lieus protégés par la loi et où les activités doivent être restreintes. Le Parc d’État Ibitipoca (PEI) est localisé dans l'état de Minas Gerais. Ce travail vise à étudier et cartographier les conflits d'utilisation et d'occupation des sols dans les régions de la ZT du PEI susceptibles à l'érosion grâce à utilisation des techniques d'analyse d'information géographiques.

Mots-clé: Zone tampon, système d'information géographique, la susceptibles à l'érosion.

* O texto deste artigo corresponde a uma comunicação apresentada no III Congresso Internacional, I Simpósio Ibero-Americano e VIII Encontro Nacional de Riscos, tendo sido submetido em 30-01-2015, sujeito a revisão por pares a 30-04-2015 e aceite para publicação em 06-07-2015.

Este artigo é parte integrante da Revista Territorium, n. ${ }^{\circ} 22,2015,{ }^{\circ}$ RIscos, ISSN: 0872-8941. 


\section{Introdução}

No Brasil, a conservação das últimas florestas tropicais vem sendo prioridade do governo, que se preocupa com o aumento do número de áreas sob proteção legal. Atualmente, o país conta com várias Unidades de Conservação da Natureza (UC), sendo elas essenciais à manutenção da biodiversidade, pois preservam um maior número possível de espécies.

As áreas no entorno das unidades de conservação (Parques) no Brasil também são protegidas por lei e são denominadas de Zonas de Amortecimento (ZA) ou zonas tampão. A ZA tem o propósito de reduzir os impactos negativos sobre as áreas protegidas, por meio de regras de uso e ocupação do solo.

Segundo R. Miller (1997) a Zona de Amortecimento é determinada com intuito de filtrar os impactos negativos das atividades externas a ela, como a poluição, o barulho, a presença de espécies exóticas e o avanço da ocupação humana.

O presente artigo visa estudar e mapear a susceptibilidade à erosão na ZA do Parque Estadual do Ibitipoca (PEI) afetada pelos tipos de solo, pelos níveis de declividade e pelo uso e ocupação do solo.

A susceptibilidade à erosão pode ser compreendida como "características inerentes do meio, representando a fragilidade do ambiente em relação aos escorregamentos" (S. Saito, 2004, p. 32).

Segundo I. Veyret (2007), áreas muito íngremes, que são exploradas por atividades antrópicas, estão mais propícias a movimentos de massa e por isso exigem um levantamento preciso das condições que possam agravar o risco ambiental, que neste caso "resultam da associação entre os riscos naturais e os riscos decorrentes de processos naturais agravados pela atividade humana e pela ocupação do território" (I. Veyret, 2007, p. 63).

O diagnóstico de áreas com risco à erosão tem sido utilizado como uma ferramenta importante na gestão de áreas protegidas por lei. Esse diagnóstico é feito com o auxílio do geoprocessamento, que tem como produto final mapas de inventário, de susceptibilidade e de risco.

Para J. Xavier-da-Silva (1992), o uso de técnicas de geoprocessamento permite adquirir conhecimento sobre as relações entre fenómenos ambientais, possibilitando diagnosticar áreas de risco.

Por meio do Sistema de Informação Geográfica (SIG) é possível obter mapas com precisão e rapidez, representando uma ferramenta essencial no estudo do ambiente. A avaliação de área susceptível à erosão é uma etapa importante para a definição de práticas adequadas de manuseamento e conservação (L. Faria et al., 2003).

\section{Área de Estudo}

O PEI, com uma área de $14,88 \mathrm{Km}^{2}$, pertence aos municípios de Lima Duarte e de Santa Rita de Ibitipoca, no Estado de Minas Gerais (Brasil). A entrada principal está localizada a, aproximadamente, três quilómetros do distrito de Conceição do Ibitipoca. Em 1973, o Governo de Minas Gerais criou o parque, por meio da Lei Estadual $n^{\circ} 6.126$.

A zona de amortecimento do Parque Estadual do Ibitipoca foi estabelecida em 2006, por meio do primeiro Plano de Manejo. Com uma área de aproximadamente $100,41 \mathrm{~km}^{2}$, a ZA que envolve o PEI, está inserida nos municípios de Lima Duarte, de Santa Rita do Ibitipoca e de Bias Fortes (fig.1).

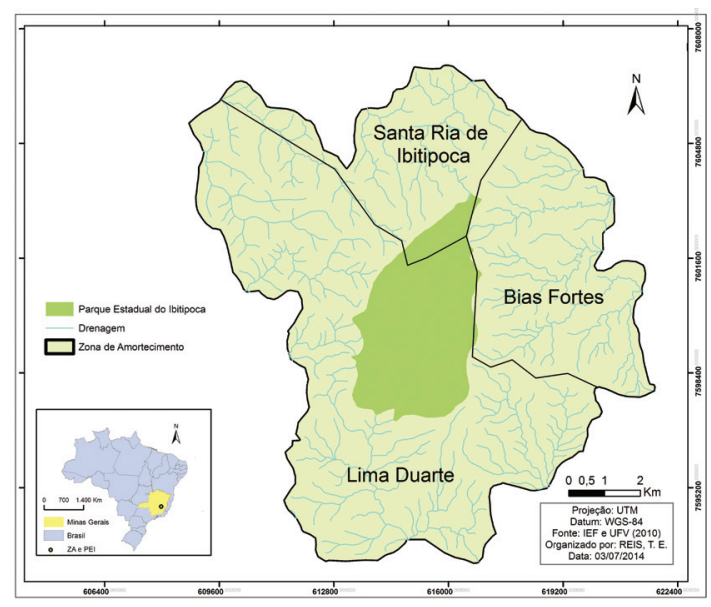

Fig. 1 - Mapa de localização da Zona de Amortecimento Parque Estadual do Ibitipoca (MG) (Fonte: IEF e UFV, 2010).

Fig. 1 - Location map of the Buffer Zone - Ibitipoca State Park (MG) (Source: IEF e UFV, 2010).

O PEI é uma importante área natural protegida que, além da sua fauna e flora rica, possui trilhas, grutas, miradouros, praias, piscinas naturais e cachoeiras. 0 PEI está aberto ao público todos os dias, entre as 7 às $17 \mathrm{~h}$, oferecendo aos visitantes diversas opções de lazer e de atividades ao ar livre, tais como, o "circuito das águas", "circuito do pião" e a "janela do céu”. O Parque possui também infraestrutura de apoio, um camping, um restaurante e um centro de atendimento à visitantes e turistas.

A população que vive em redor do PEl utiliza a área para subsistência, criando gado e cultivando, por isso, na ZA o uso e ocupação do solo predominante é a pastagem e a agricultura (plantação de hortaliças), que juntas representam $50 \%$ da forma de uso. A mata também é encontrada em grandes extensões, em aproximadamente $33 \%$ de toda a ZA e $14 \%$ encontram-se com mata em processo de regeneração. 
Apesar de ser proibida a plantação de eucalipto na zona de amortecimento do PEI, esse tipo de cultivo abrange cerca de $1,36 \%$ da área estudada. A presença de quatzito em decomposição na região é constante, abrangendo $1,5 \%$ de toda ZA.

Também foram constatadas a presença de solo exposto, 0,08\%, corpos hídricos, 0,04\%, plantações, 0,15\% e áreas construídas, $0,12 \%$ sendo essas compostas por casas, ranchos e currais (fig. 2).

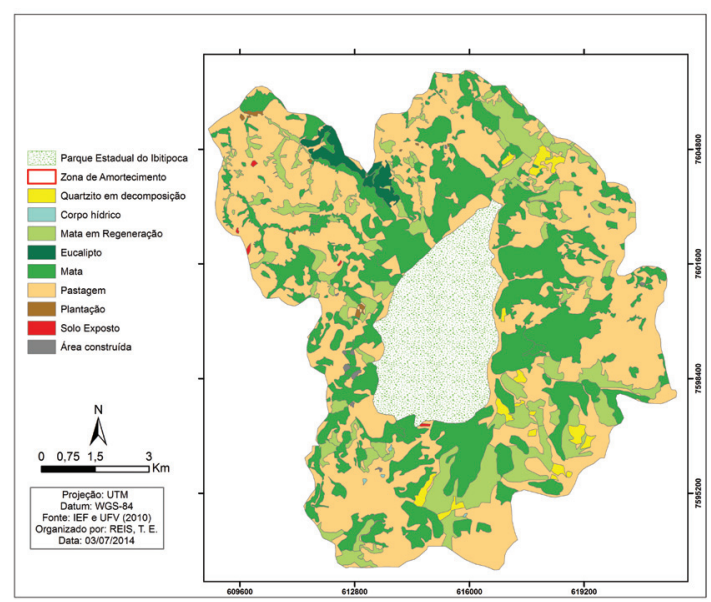

Fig. 2 - Mapa de uso e ocupação do solo da Zona de Amortecimento - Parque Estadual do Ibitipoca (MG)

(Fonte: IEF e UFV, 2010).

Fig. 2 - Map of use and soil occupation of Buffer Zone Ibitipoca State Park (MG) (Source: IEF e UFV, 2010).

O relevo no Parque e na ZA é bem acentuado e possui altitudes que variam de 800 a 1780 metros. As áreas nos seus arredores "são caracterizadas por morros, colinas, formas intermediárias e vales em $\mathrm{V}$, que pertencem ao -Planalto de Andrelândia, com relevos desenvolvidos em rochas metassedimentares do Grupo Andrelândia e à Depressão de Belo Horizonte, desenvolvida localmente em rochas do Gnaisse Piedade" (G. Rodela, 1998, p.166).

R. Nummer et al., (2012, p.115) afirmam que o relevo da área do Parque Estadual do Ibitipoca apresenta geoformas como: “cristas anticlinais; ondulações nas cristas; vertentes verticalizadas (abruptas ou retilíneas); em patamares estruturais; em talus; esfoliadas; vales primitivos (desenvolvidos em sinclinais), e / ou erosivos (desenvolvidos por águas pluviais ou fluviais; desabamentos / erosão subterrânea); em garganta (vertente e paredão); simétricos em garganta como paredões ou vertentes abruptas, formas isoladas morrotes; pontes naturais; cavernas; bancos de areia; áreas alagadiças; concavidades (formas subsidentes) correspondentes a tetos de cavernas, esporões e cuestas que mergulham na direção dos vales do rio do Salto e Córrego da Mata. Estes dois afluentes construíram escarpas acidentadas, com contrastes de topografia na ordem de 50 a 100m, marcados por cacimbas e marmitas".
Os elevados declives constituem um fator agravante para os movimentos de massa e a ocorrência da erosão. $\mathrm{Na}$ área de estudo, as classes de declive foram determinadas a partir das Leis Federais 6.766/1979 e 12.651/2012 e Classificadas em: 0-5\%, 5-10\%, 10-20\%, 20-30\%, 30-47\%, 47-100\% e > 100\%. As áreas com maior declividade estão próximas à fronteira do $\mathrm{PEI}$, predominando a norte, a leste e a oeste. (fig. 3 )

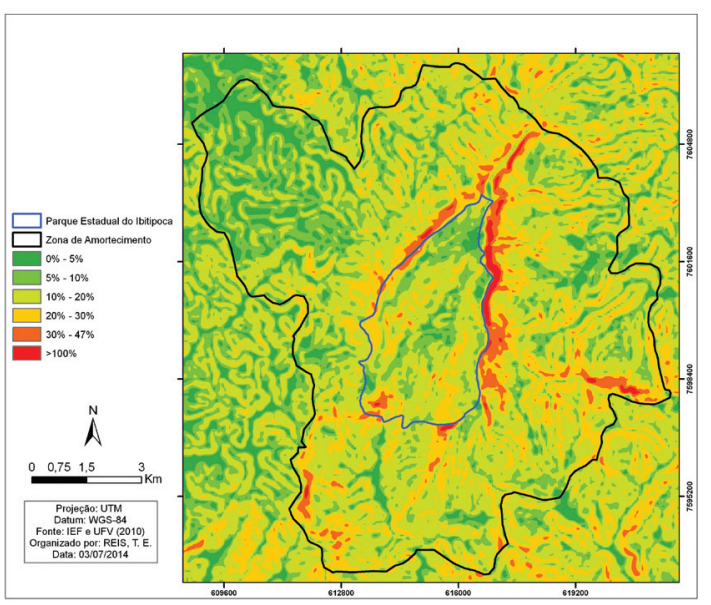

Fig. 3 - Mapa de declividade da Zona de Amortecimento Parque Estadual do Ibitipoca (MG) (Fonte: IEF e UFV, 2010).

Fig. 3 - Slope map of the Buffer Zone - Ibitipoca State Park (MG). (Source: IEF e UFV, 2010).

O solo da região é bastante diversificado, pois os tipos (latossolos, cambissolos e neossolo) dependem muito da posição topográfica, da estrutura e da forma do relevo (R. Nummer et al., 2012).

O tipo predominante de solos na ZA é o cambissolo háplico com o Latossolo Vermelho-Amarelo e Cambissolo Húmico com $57 \%$ nas áreas norte, leste e sul da ZA, enquanto $15 \%$ é ocupado por cambissolo háblico e $12 \%$ por cambissolo háplico e Latossolo Vermelho-Amarelo, ambos a oeste. No entanto, há presenças do neossolo litólito e afloramentos rochosos com Camibissolo Húmico (9\%) ao redor da divisa do $\mathrm{PEI}$, de Latossolo Vermelho Amarelo e Argissolo Vermelho em pequenas áreas espalhadas na ZA (7\%) e de Cambissolo Húmico, Háplico e Latossolo Vermelho-Amarelo (1\%) em alguns pontos da ZA. (fig. 4).

\section{Metodologia}

A metodologia utilizada foi a análise multicritério. M. Moura (2007), no seu estudo, apresentou uma metodologia, com base no SIG e na análise multicritério: “...[1] seleção das principais variáveis que caracterizam um fenômeno, já realizando um recorte metodológico de simplificação da complexidade espacial; [2] representação da realidade segundo diferentes variáveis, organizadas em camadas de informação; 


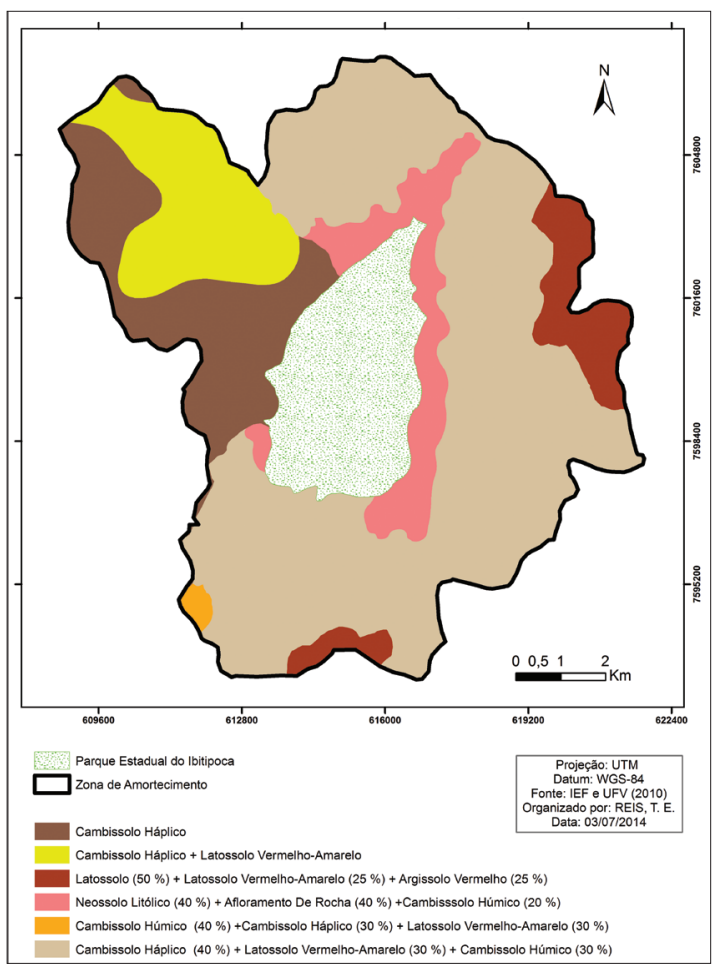

Fig. 4 - Mapa Pedológico da Zona de Amortecimento - Parque Estadual do Ibitipoca (MG) (Fonte: IEF e UFV, 2010).

Fig. 4 - Pedological map of the Buffer Zone - Ibitipoca State Park (MG) (Source: IEF e UFV, 2010).

[3] discretização dos planos de análise em resoluções espaciais adequadas tanto para as fontes dos dados como para os objetivos a serem alcançados; [4] promoção da combinação das camadas de variáveis, integradas na forma de um sistema, que traduza a complexidade da realidade; finalmente, [5] possibilidade de validação e calibração do sistema, mediante identificação e correção das relações construídas entre as variáveis mapeadas." (M. Moura, 2007, p. 2900)

Utilizando o programa de geoprocessamento ArcGIS 10.1 foi elaborado o mapa de uso e ocupação do solo , com base nas imagens de satélite em mosaico Rapideye, com uma resolução espacial de 5 metros, cedida pelo Instituto Estadual de Florestas de Minas Gerais (IEF), dos anos de 2009/2010. Para corrigir os erros de georreferenciação e de ortorretificação foi usada a ferramenta Topology.

Por meio das curvas de nivel à escala de 1:50.000, cedidas também pelo IEF, foi possível realizar o Modelo Digital de Elevação (MDE). Com base no MDE foi criado o mapa de Declividade utilizando a ferramenta Slope. Os dados utilizados no mapa pedológico à escala de 1:500.000 foram cedidas pelo Departamento de Solo da Universidade Federal de Viçosa, o que se tornou compatível com a escala de análise.

Após a elaboração dos mapas de declividade, pedológico e uso e ocupação do solo , foram atribuídos pesos em percentagem a cada mapa ( uso e ocupação do solo $35 \%$,
Declividade $35 \%$ e tipos de solo $30 \%$ ). A cada classe dos mapas foram também atribuídos pesos de 1 a 10. 0 critério de atribuição dos pesos e notas baseou-se no método Delphi. Segundo Moura (2007), o método Delphi é o que melhor se adequa ao uso da análise multicritério. (QUADRo I).

Os mapas temáticos foram cruzados, utilizando-se o método de álgebra de mapas no ArcGIS 10.1, para se obter o mapa de susceptibilidade. O mapa foi reclassificado em classes de baixa, media e alta susceptibilidade.

Foram identificadas as propriedades existentes na zona de amortecimento através das imagens de satélite. Para conhecer a classificação de susceptibilidade à erosão das propriedades, foi realizada a análise espacial entre as propriedades e o mapa de susceptibilidade.

Foram efetuados, em campo, inquéritos aos proprietários indentificando: nome, coordenadas geográficas da propriedade, dimensão da propriedade, tempo de posse e a utilização da propriedade, existência na propriedade de rios ou córregos, de topo de morros e de área de preservação permanente (APP). Também foi indagado se o propriedtário sabia que está dentro de uma zona de amortecimento e se havia conhecimento das leis que a protege, qual foi a última queimada na propriedade e como ela foi controlada, quais informações que o entrevistado tem sobre a UC e se existe algum programa de governo que auxilia os produtores rurais e fomenta o turismo. Foi realizada uma amostragem de $17 \%$ equivalente a 20 propriedades. Este valor percentual amostral foi considerado ssatisfarório devido à grande dificuldade de acesso às propriedades.

Depois de traçar o perfil dos proprietários foi elaborado um mapa das propriedades inseridas em áreas de de susceptibilidade à erosão.

\section{Resultados}

Os resultados possibilitaram identificar que 19\% da ZA está classificada com alta susceptibilidade à erosão e encontra-se em locais com declividade de $47 \%$ a $100 \%$, em solos do tipo neossolo litólico, e em áreas com solo exposto e plantações de eucalipto. Estas áreas localizam-se predominantemente ao norte e este do PEI, devido ao elevado declive. Também se encontram algumas áreas de alta susceptibilidade a sul e a sudeste da ZA do PEI, devido à predominância de pastagem (área degradadas), associadas aos latossolos vermelhoamarelo que são de alta erodibilidade. As áreas de média susceptibilidade estão em grande parte da ZA, abrangendo, aproximadamente, $58 \%$ de sua extensão. As áreas de baixa susceptibilidade ocupam 23\% da ZA e estão localizadas a este e a oeste da ZA do Parque .

A fig. 5 mostra um gráfico com a percentagem das áreas classificadas em baixa, média e alta susceptibilidade à erosão, de acordo com o estudo. 
Foram identificadas 120 propriedades na zona de amortecimento do PEI, 29 delas encontram-se em áreas classificadas com baixa susceptibilidade à erosão, o que representa $24 \%$ do total, já 80 propriedades estão em média susceptibilidade, correspondendo a $67 \%$, e 11 localizadas em área de alta susceptibilidade, o que equivale a $9 \%$,como é possível observar na fig. 6 .

O Mapa de susceptibilidade à Erosão mostra as áreas que foram classificadas como baixa, média e alta, bem como os locais em que as propriedades estão presentes nessas áreas (fig. 7).

Após os inquéritos, foi possível dividir o perfil das propriedades em cinco categorias: pousadas; fazenda

\section{Susceptibiliade à Erosão}

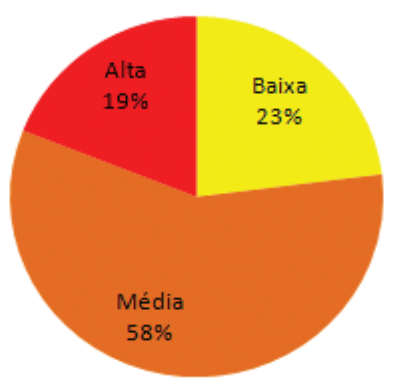

Fig. 5 - Gráfico de Susceptibilidade à Erosão na Zona de Amortecimento - Parque Estadual do Ibitipoca (MG).

Fig. 5 - Graphic of Susceptibility to erosion in the Buffer Zone - Ibitipoca State Park (MG). do Engenho; propriedades não exploradas por nenhuma atividade económica (agropecuária ou turismo); pequenos proprietários e as grandes propriedades produtoras de eucalipto. A fig. 8 mostra as propriedades existentes na ZA e as que foram inqueridas.

As pousadas representam $15 \%$ das propriedades inquiridas, e localizam-se a sul e ao oeste do PEI, próximas da estrada de acesso ao Parque. De acordo com os inquiridos, as construções foram efetuadas antes da delimitação da ZA e por isso não afetaram em nada as construções. Destaca-se o Hotel de Lazer

\section{Propriedades existentes}

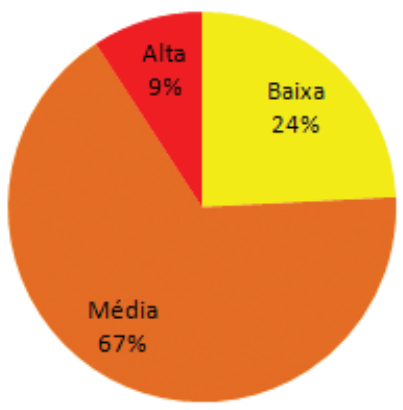

Fig. 6 - Gráfico das propriedades classificadas com Susceptibilidade à Erosão na Zona de Amortecimento - Parque Estadual do Ibitipoca (MG).

Fig. 6 - Graphic of properties classified as susceptibility to erosion in the Buffer Zone - Ibitipoca State Park (MG).

QuAdRo I - Pesos dos mapase notas das classes utilizados na classificação.

TABLE I - Weights of maps and notes of the classes used in the classification.

\begin{tabular}{|l|c|}
\hline \multicolumn{2}{|c|}{ Uso e ocupação do solo - peso: $35 \%$} \\
\hline Classificação & Notas \\
\hline Mata & 1 \\
\hline Mata em regeneração & 3 \\
\hline Pastagem & 4 \\
\hline Área construída & 6 \\
\hline Plantação & 6 \\
\hline Areal & 7 \\
\hline Eucalipto & 7 \\
\hline Solo exposto & 8 \\
\hline
\end{tabular}

\begin{tabular}{|l|r|}
\hline \multicolumn{2}{|c|}{ Declividade - peso: $35 \%$} \\
\hline $0 \%-5 \%$ & Notas \\
\hline $5 \%-10 \%$ & 1 \\
\hline $10 \%-20 \%$ & 2 \\
\hline $20 \%-30 \%$ & 4 \\
\hline $30 \%-47 \%$ & 5 \\
\hline $47 \%-100 \%$ & 6 \\
\hline$>100 \%$ & 8 \\
\hline
\end{tabular}

Tipos de Solos - peso: $30 \%$

\begin{tabular}{|l|c|}
\hline \multicolumn{1}{|c|}{ Classificação } & Notas \\
\hline Cambissolo Háplico & 8 \\
\hline Cambissolo Háplico + Latossolo Vermelho-Amarelo + Cambissolo Húmico & 8 \\
\hline Cambissolo Háplico + Latossolo Vermelho & 7 \\
\hline Neossolo Litólico + Afloramento de Rocha + Cambissolo Húmico & 10 \\
\hline Latossolo Vermelho-Amarelo + Latossolo Vermelho + Cambissolo Háplico & 3 \\
\hline Cambissolo Húmico + Cambissolo Háplico + Latossolo Vermelho-Amarelo & 6 \\
\hline
\end{tabular}




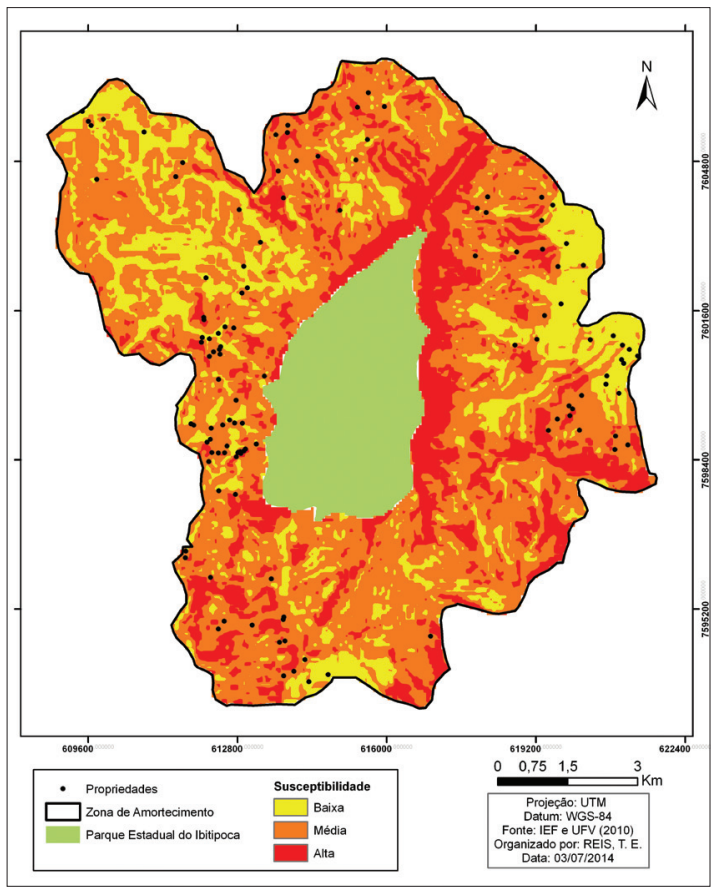

Fig. 7 - Mapa de Susceptibilidade à Erosão na Zona de Amortecimento - Parque Estadual do Ibitipoca (MG).

Fig. 7 - Map of Susceptibility to erosion in the Buffer Zone Ibitipoca State Park (MG).

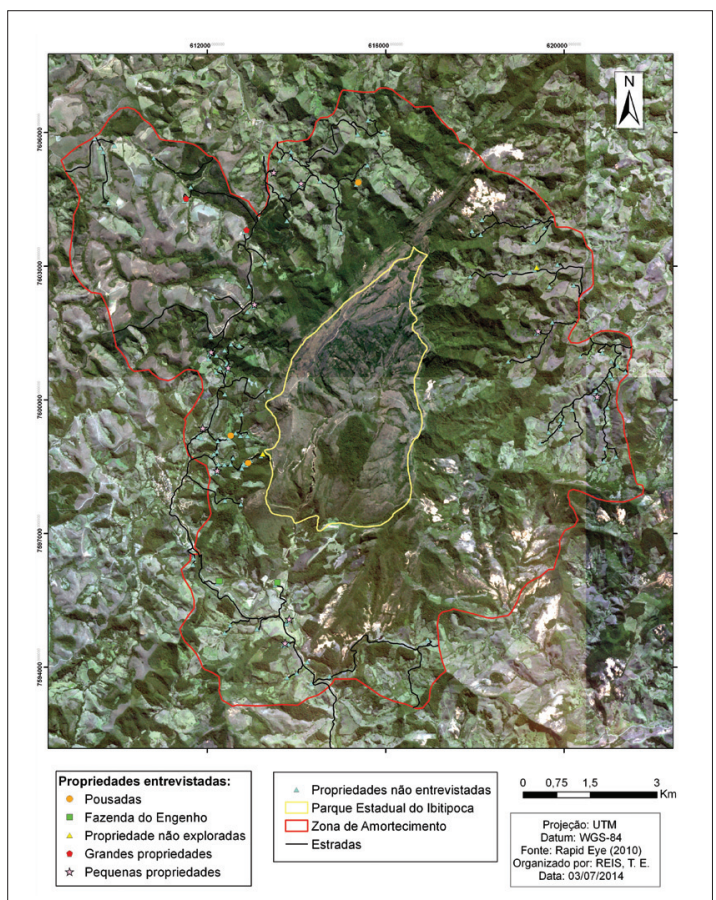

Fig. 8 - Mapa das propriedades na Zona de Amortecimento Parque Estadual do Ibitipoca (MG).

Fig. 8 - Map of the properties in the Buffer Zone - Ibitipoca State Park (MG).

Serra do Ibitipoca, que segundo o proprietário, possui uma Reserva Particular do Patrimônio Natural (RPPN) que ocupa $33 \%$ de sua propriedade, uma estação de tratamento de esgotos, e uma unidade de reciclagem de lixo produzido no hotel.
A Fazenda do Engenho possui aproximadamente 30.000 $\mathrm{Km}^{2}$ de terra em redor do Parque e tem como objetivo proteger a fauna e a flora da região. As propriedades que possuem cachoeiras ou grutas podem ser visitadas pelos hóspedes da pousada. Esta propriedade forma uma faixa de proteção (armotecimento) favorecendo, assim, o intercâmbio de espécies.

Também foi possível mapear propriedades a este e a oeste na ZA do PEI que não são exploradas economicamente. Estas contabilizam 10\% dos inquiridos. De acordo com os proprietários, estes foram proibidos (pela fiscalização do Parque) de explorarem suas terras e tiveram que deixar retornar a vegetação de floresta.

Os proprietários, que exploram as suas terras com plantação de eucalipto, e em geral não moram no local, vêm utilizando a propriedade como forma de lazer. Estas propriedades localizam-se a oeste na ZA do PEI e correspondem a $10 \%$ dos inquiridos.

Os pequenos proprietários, nascidos e criados na região, utilizam as suas terras como forma de subsistência. Estas propriedades localizam-se também a oeste na ZA do PEI e corresponde a $50 \%$ dos inquiridos. Segundo os proprietários, a fiscalização tem sido feito por parte das autoridades.

O QuADRo II discrimina a categoria e o número de propriedades nas diferentes classes de susceptibildade à erosão.

A localização das propriedades estão expostas na fig. 9, na qual mostra o mapa de susceptibilidade à erosão com as propriedades existentes nestas áreas.

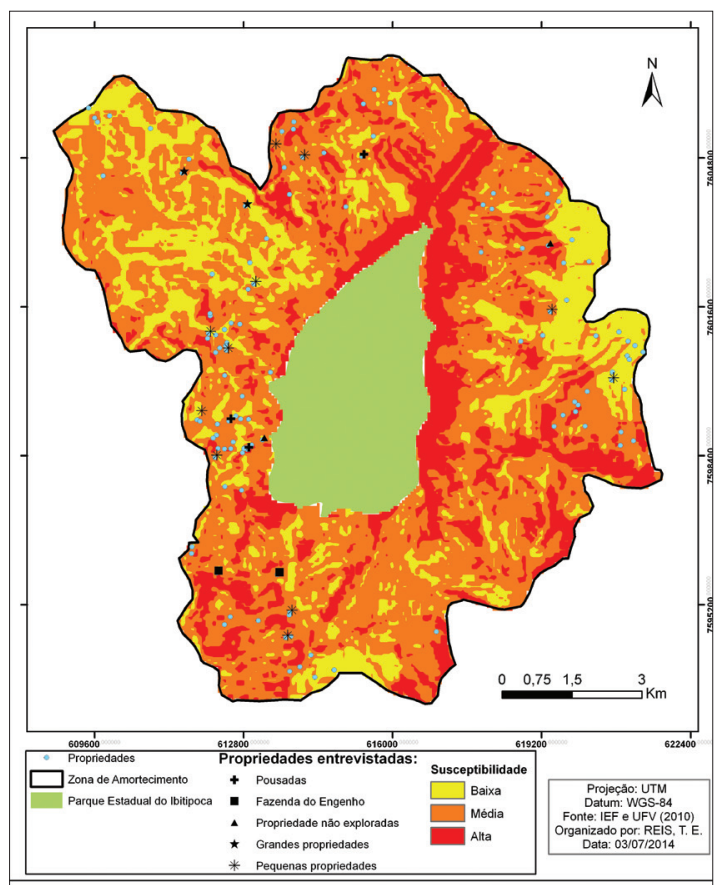

Fig. 9 - Mapa de susceptibilidade à erosão na Zona de Amortecimento - Parque Estadual do Ibitipoca (MG).

Fig. 9 - Map of susceptibility to erosion in the Buffer Zone Ibitipoca State Park (MG). 
territorium 22

Quadro II - Propriedades classificadas como susceptíveis à erosão.

TABLE II - Properties classified as susceptible to erosion.

\begin{tabular}{|ccccccc|}
\hline & $\begin{array}{c}\text { Pequenas } \\
\text { Propriedades }\end{array}$ & Pousadas & $\begin{array}{c}\text { Propriedades } \\
\text { não } \\
\text { exploradas }\end{array}$ & $\begin{array}{c}\text { Fazenda } \\
\text { do } \\
\text { Engenho }\end{array}$ & $\begin{array}{c}\text { Grandes } \\
\text { propriedades }\end{array}$ & Total \\
Baixa & 3 & & 2 & 2 & 1 & 4 \\
Média & 7 & 2 & 1 & & 2 & 14 \\
Alta & 1 & 3 & 2 & 2 & 2 & 20 \\
Total & 11 & & & & & \\
\hline
\end{tabular}

\section{Conclusão}

A partir dos resultados apresentados no presente trabalho, é importante ressaltar que as áreas classificadas com alta susceptibilidade à erosão deverão sofrer uma intervenção dos gestores para que o risco do processo erosivo não se torne uma realidade. As onze pequenas propriedades terão que ter prioridade no programa do governo e deverão ser monitorizadas. Os gestores também terão que dar uma grande atenção para as áreas classificadas como médias susceptibilidade à erosão, cerca de $58 \%$, pois estas podem avançar para o alto grau caso não sejam preservadas.

O diagnóstico das áreas susceptíveis à erosão na ZA do PEI dará auxílio aos gestores na caracterização e no controle dos locais susceptíveis à erosão, possibilitando assim, uma gestão adequada da região, evitando que os eventuais impactos nas ZA possam avançar para o interior da área protegida.

É indispensável manter um equilíbrio entre a manutenção dos recursos ambientais e a sustentabilidade social, cultural e econômica da população envolvida nestas áreas.

É importante destacar que cumprir os objetivos das UC não é somente entender o seu significado e a sua função socioambiental. É fundamental que sejam criados espaços de diálogos e de decisões entre os especialistas, gestores, promotores públicos, população local, visitantes e empreendedores municipais. Além disso, é preciso viabilizar atividades sócio-educativas com toda a população da região, incrementando o emprego, os negócios (principalmente àsqulas vinculados ao turismo sustentável) e a cidadania.

As ferramentas de geoprocessamento, tais como, SIG, deteção remota e GPS, são importantes na gestão das UCs, pois permitem a interação e o manuseamento de uma grande quantidade de dados, precisos e rápidos, obtidos com um alto grau de confiabilidade. Essas ferramentas permitem um planejamento mais dinâmico e eficiente, auxiliando na gestão, nas tomadas de decisões e nas avaliações das ações permitidas no Parque e na ZA.

Com o uso do geoprocessamento foi possível ter análises mais precisas sobre condicionantes físicas e assim usálas no apoio à tomada de decisão, contribuindo para novos estudos sobre a UC e sua ZA. Espera-se que a presente pesquisa subsidie o diagnóstico das áreas de vulnerabilidade social da ZA, possibilitando estudos mais apurados da redefinição do seus limites e o uso urbano e rural adequado à conservação e sustentabilidade.

\section{Referências bibliográficas}

ArcGis 10.1: Software. Disponível em http://www.esri. com/ licença educacional (kitlab), Laboratório de Geoprocessameno da UERJ

Faria, A. L. L., Silva, J. X, Goes, M. H. B. (2003). Análise ambiental por geprocessamento em áreas com susceptibilidade à erosão do solo na Bacia Hidrográfica do Ribeirão do Espírito Santo, Juiz de Fora (MG). Caminhos da Geografia, Uberlandia, MG, v. 4, n. 9, p. 50-65.

Ladeira, A. S. (2005). Avaliação dos impactos da visitação, capacidade de carga turística $e$ perfil dos visitantes do Parque Estadual do ibitipoca, Lima Duarte - MG (Tese de Doutorado em Ciências). Universidade Federal de Viçosa, Viçosa, MG, $129 \mathrm{f}$.

Miller, K. R. (1997). Evolução do Conceito de Áreas de Proteção - Oportunidades para o século XXI. I Congresso brasileiro de unidades de conservação, Curitiba. Anais... Curitiba: UNILIVRE. v. 1., p. 3 -21.

Moura, A. C. M. (2007). Reflexões metodológicas com o subsídio para estudos ambientais baseados em Análise de Multicritérios. Simpósio Brasileiro de Sensoriamento Remoto, 13. Florianópolis. Anais... Florianópolis: IMPE, p.2899 - 2906. http: / / marte.sid.inpe.br/col/dpi.inpe.br/ sbsr@80/2006/11.13.14.41/doc/2899-2906.pdf

Nummer, A. R., Garcia, M. G. M., Rodela, L. G., Oliveira, J. C. L., Belcavelo, R. (2012). Potencial Geoturístico do Parque Estadual da Serra do Ibitipoca, Sudeste do Estado de Minas Gerais. Anuário do Instituto de Geociências - UFRJ, Rio de Janeiro. Vol. 35, n.1, p.112-122. 
Rodela, L. G. (1998). Cerrados de altitude e campos rupestres da Serra do Ibitipoca, sudeste de Minas Gerais: distribuição e florística por subfisionomias da vegetação. Revista do Departamento de Geografia ${ }^{\circ}{ }^{12}$. Universidade de São Paulo. São Paulo. http://www.pluridoc. com/Site/FrontOffice/default.aspx?module=Files / FileDescription\&ID=2707\&state $=F$
Saito, S. (2004). Estudo analítico da susceptibilidade a escorregamento e queda de bloco no Maciço Central de Florianópolis-SC (Dissertação Mestrado em Geografia). Florianópolis. 132 p. Universidade Federal de Santa Catarina.

Veyret, Ivette. (org.) (2007). Os Riscos: O homem como agressor e vítima do meio ambiente. Ed. Contexto, São Paulo. 